\title{
Involvement of Membrane Fluidity in Endogenous Protective Processes Running on Subcellular Membrane Systems of the Rat Heart
}

\author{
A. ZIEGELHÖFFER ${ }^{1}$, I. WACZULÍKOVÁ ${ }^{2}$, M. FERKO $^{1}$, L. ŠIKUROVÁ ${ }^{2}$, \\ J. MUJKOŠOVÁ ${ }^{1}$, T. RAVINGEROVÁ ${ }^{1}$
}

${ }^{1}$ Institute for Heart Research, Slovak Academy of Sciences and Centre of Excellence, Slovak Academy of Sciences, NO REG, Bratislava, Slovakia, ${ }^{2}$ Department of Nuclear Physics and Biophysics, Faculty of Mathematics, Physics, and Informatics, Comenius University, Bratislava, Slovakia

Received March 21, 2012

Accepted July 13, 2012

\begin{abstract}
Summary
Membrane fluidity is a widely recognized biophysical variable that provides information about structural organization of the subcellular membranes exhibiting physical characteristics of liquid crystals. The term "fluidity" reflects in this case the tightness in packing of acyl parts of the membrane phospholipid molecules, a feature that may influence considerably the molecular mobility and via that also the sensitivity and reactivity of membranebound transporters, receptors and enzyme systems. Data presented in this review are aimed to demonstrate the substantial role of changes in membrane fluidity occurring in the processes associated with endogenous protection observed in cardiac sarcolemma and mitochondria in diverse pathologies, particularly in diabetes and hypertension.
\end{abstract}

\section{Key words}

Rat heart sarcolemma - Mitochondria - Membrane fluidity • Diabetes • Hypertension • Endogenous protection

\section{Corresponding author}

Attila Ziegelhöffer, Institute for Heart Research, Slovak Academy of Sciences, Dúbravská cesta 9, 84005 Bratislava, Slovakia. E-mail: usrdzigy@savba.sk

\section{Introduction}

Responsible body of the membranes consist of an inversely oriented bi-layer of parallel arranged phospholipid molecules with their non-flexible polar heads facing the aqueous environment on either side of the membrane. Because of their structural organization the subcellular membranes behave like a liquid crystal. Receptors, various transporters and systems involved in the transfer of signals are embedded in the membranes some of them even span the lipid bilayer completely. However, proper function of these systems requires adequate mobility of their molecules. This mobility is secured by flexibility of acyl chains of the membrane phospholipids. The less tightly are packed the acyl chains of phospholipids the more fluid is the lipid bilayer of membranes and the more free may move the molecules of embedded systems. This makes membrane fluidity a potent modulator of membrane functions.

Role of membrane fluidity in function of subcellular membranes and metabolism

It has been accumulated much evidence that diverse impulses targeting the membranes may increase or decrease MF. Chemical compounds, including pharmaceuticals, may immerse into the membrane, depending on hydrophobicity of their molecules and, modulate the MF. Finally, spontaneous or evoked changes in the chemical composition of membranes may also alter the MF. High sensitivity of MF to various influences as well as the differences in specific properties of different subcellular membranes represent the reasons 
why the physiological range of changes in MF was not yet demarcated sufficiently.

In the past 30 years a considerable amount of information concerning the involvement of different membrane systems such as sarcolemma, sarcop-lasmic reticulum, and mitochondria in heart function and metabolism has appeared in the literature. It became absolutely clear that these membrane structures not only represent morphological barriers between various myocardial cell compartments but they are also intimately associated with a wide variety of molecular, biochemical and biophysical events occurring both in the cell compartments and in the membranes itself (Ziegelhöffer et al. 2009).

Control over the ionic fluxes as well as the neurohormonal and calcium-mediated cell signaling also belongs to unique properties of the cardiac sarcolemmal membranes (Dhalla et al. 1977, Pierce and Dhalla 1985).

Mitochondria are most frequently discussed because of their association with respiration and oxidative phosphorylation. Less frequently is mentioned that they also provide the control over the above processes (Sordahl and Schwartz 1967, Schwartz 1971/72). More recently it was shown that mitochondria may also exert control over formation of the ephemeric energy transition pores, also termed as mitochondrial contact sites, in their own membranes (Knoll and Brdiczka 1993, Bakker et al. 1994, Ziegelhöffer-Mihalovičová et al. 1997, 2002, Ziegelhöffer et al. 2009).

Role of membrane fluidity in physiological and pathophysiological processes

It was confirmed that regardless of the type of membrane, the MF may have effective control over many physiological processes (Shinitzky 1984, Gennis 1989). Since MF is reflecting the interplay between the membrane lipids and proteins it represents a variable with virtually unlimited range of influence on the milieu in which the membrane-bound systems are acting. Because of its basic dependence on a specific composition of lipids, changes in MF may also be induced by alterations in the diet or metabolism (Waczulíková et al. 2010). Perturbations that increase the area per lipid molecule, such as higher degree of phospholipid (PL) unsaturation, lower average length of the acyl chains, particular shifts in the lipid profile, decreased level of cholesterol etc., all result in an increase in MF (Gennis 1989, Watala 1993). Free radicals and diverse chemical compounds, mainly pharmaceuticals, may interact with membranes and modulate MF (Taam et al. 1979). In addition, physiological and pathological impulses, including seasonal changes, which target the membranes, may also change MF. According to our findings, elevated MF of rat heart mitochondria observed in the winter/spring season was accompanied with a considerable increase in the mitochondrial $\mathrm{Mg}^{2+}$-ATPase activity (Mujkošová et al. 2008). On the other hand, lowered MF of the diabetic rat heart sarcolemma was found to be associated with a decrease in $\mathrm{Ca}^{2+}$ influx (Gøtzsche 1991, Ziegelhöffer et al. 1996, 2003b, Ziegelhöffer-Mihalovičová et al. 2003) as well as in the Na,K-ATPase activity (Ziegelhöffer et al. 1997, 2003a, Ziegelhöffer-Mihalovičová et al. 2003). Finally, estimation of MF parallely with one or more purposefully chosen dominant membrane functions, enabled to reveal that some diabetes-induced alterations in the heart sarcolemma and mitochondria, previously thought to be pathologic, belong, in reality, to the mechanisms of endogenous protection (ZiegelhöfferMihalovičová et al. 2003, Ziegelhöffer 2005, Ferko et al. 2006).

Aim of the present paper is to document the regulatory role of MF for the function of membranebound systems in the heart sarcolemma and mitochondria in both health and disease. It provides a selection of findings obtained with biochemical and physiological techniques completed with spectroscopical estimation of MF. Presented data extend the previous knowledge and/or revise some older conceptions about the role of MF in various physiological and pathological situations.

\section{Methods for studying subcellular membranes}

Membrane dynamics covers virtually all modes of molecular motion in the membrane, among which $\mathrm{CH}_{2}$-bond vibrations, lipid rotation (about the long axis), lateral "hopping" of lipids and proteins and rotation of protein are discussed most frequently (Gennis 1989). In selection of adequate technique for measurement of the above properties the rate of their molecular motion should be taken into account. If the components move slowly with respect to the speed of measurement, the technique yields a "static", so called frozen picture of the membrane event. When the molecules move rapidly, then a time-resolved fluorescence spectroscopy provides the appropriate tool to track fine features of the movement. Quick, cost-effective and therefore more frequently used is the steady-state fluorescence anisotropy method. It 
offers a time-averaged picture of movements of sensed components, since the speed of membrane motions is considerably higher than the time used for their detection.

In studying cardiac cell and membrane functions in both health and pathological conditions we utilized the following methods:

i) Fluorescence spectroscopy and fluorescence or confocal laser scanning microscopy, with employing exogenous fluorescent probes (Fig. 1). These techniques have proved useful in the investigation of membrane fluidity, protein-lipid interactions, membrane permeability and transport across the membranes (Ziegelhöffer et al. 1997, 2000, Šikurová et al. 1997, 2000, Máleková et al. 2007, Waczulíková et al. 2008) as well as selected electrical properties of the membranes (Waczulíková et al. 2000, 2007, Zvarík and Šikurová 2008). For the accurate cell edge extraction in cellvolume determination from microscopic images, a parametric active contour algorithm by Kass et al. (1988) was used. ii) Voltamperometry, to investigate some membrane-related functions of cardiac myocytes and their mitochondria such as respiratory chain function and oxidative phosphorylation rate (Ziegelhöffer 2005, Ferko et al. 2006, Uličná et al. 2008);

iii) Physiological methods such as isolated perfused "Langendorff" heart, either for testing the effect of changes in subcellular membranes on functional parameters of the heart (Ravingerová et al. 1997, 2000, Dobaczewski et al. 2006) or to isolate cardiomyocytes (Cagalinec et al. 2006, Waczulíková et al. 2007);

iv) Biochemical, particularly enzymological methods (Ziegelhöffer et al. 2003a, Breier et al. 1995, Ferko et al. 2008), techniques of cryoelectron microscopy (Waczulíková et al. 2007) and methods of biostatistics (Waczulíková et al. 2002, 2007, Waczulíková and Slezák 2009). All these methods are utilized in characterization of alterations in the activity of membrane-bound enzymes and ion transport systems associated with changes in MF.

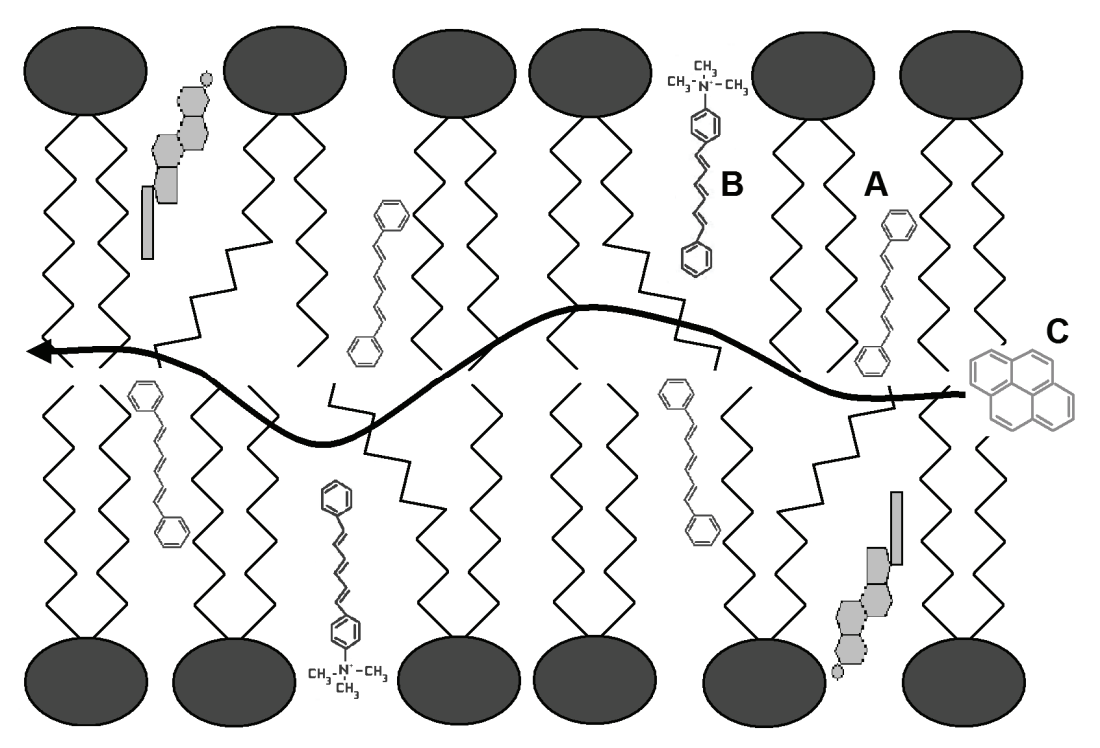

Fig. 1. Location of three of the most widely used fluorescent probes in membrane lipid bilayers, DPH (A), TMA-DPH (B) and pyrene (C). Adapted from Waczulíková et al. Physiol Res 59 (Suppl 1): S9-S17, 2010.

\section{Measuring of membrane fluidity}

MF is measured by recording a fluorescence signal which reflects the motion of membrane-permeable fluorescent probes, often with preferred orientations, in the respective parts of the membrane bilayer (Fig. 1). The probe should be chosen so that its emission maximum is out of range of the background signal, i.e. out of sample autofluorescence region. This indicates that interpretation of the obtained experimental data depends on both, the method and the probe applied.

Most measurements are made in steady-state condition with continuous excitation and emission. Principles of the measurement may be briefly described as follows: Polarization $P$ or anisotropy $r$ of the light emitted by the fluorescent probe is dependent on the orientation of its molecular transition dipole moment with respect to the direction defined by the polarizers (parallel and perpendicular) used to record the fluorescence components. Both components of intensities emitted by the fluorescent probe, $I_{I I}$ and $I_{\perp}$, are registered and their values are used to calculate the steady-state anisotropy value $r_{s}$ : 


$$
r_{s}=\frac{I_{I I}-I_{\perp}}{I_{I I}+2 I_{\perp}}
$$

Results represent an average value $r_{s}$, which is, however, related to both, the lifetime of the excited state and the rotational correlation time of the probe. This indicates that steady-state anisotropy measurements are sensitive to both the rate of motion and any constraints to that motion. Hence, the information about the dynamics and molecular order of the motion became intermixed. Nevertheless, the information on structural ordering of lipid molecules prevails (Shinitzky 1984, Gennis 1989). Details regarding the working protocols for measuring MF with the fluorescent probes are presented in our previous papers (Waczulíková et al. 2007, Waczulíková et al. 2008, Ziegelhöffer et al. 2009).

To evaluate MF in our experiments we used a parameter $r_{s}$ (1) of a fluorescent probe 1,6-diphenyl1,3,5-hexatriene (DPH) or its cationic derivative 1-[4(trimethylamino)phenyl]-6-phenyl-1,3,5-hexatriene (TMA-DPH). DPH partitions favourably into membranes, it has an intense fluorescence, it is assumed not to bind to proteins, and it is sensitive to the physical state of the membrane. Aqueous solution of DPH alone has a negligible fluorescence (Shinitzky 1984, Gennis 1989). Therefore, the fluorescence signal from labelled membranes could be solely ascribed to DPH molecules in the membrane. DPH incorporates into the hydrocarbon inside of membranes, whereas its cationic derivative TMA-DPH is located closer to the membrane surface (Fig. 1). Thus, the recorded values of fluorescence anisotropy report about MF in both parts the membrane lipid bilayer.

Each newly designed experiment requires a series of measurements to investigate the homogeneity of the sample, because in colloidal solutions not only particle size, but also their concentration may induce scattering. This may be prevented by dilution of the sample to a level at which no significant light scattering can be observed. The time course of DPH (or TMA$\mathrm{DPH}$ ) incorporation is derived from consecutive measurements covering a time-range of at least $1200 \mathrm{~s}$. High degree of fluorescence anisotropy indicates a high degree of structural order or vice versa, lower MF (Ziegelöffer et al. 1997, Waczulíková et al. 2007, Slezák and Šikurová 2008).

Another fluorescence probe for estimating MF is pyrene (Fig. 1; Barenholz et al. 1996, Watala et al. 2002). Monitoring of pyrene mobility in the membrane or in bilayers of lipid vesicles was preceded by pre-incubation of the membrane suspension with aqueous solution of the probe for $20 \mathrm{~min}$ at room temperature. Fluorescence of pyrene-labeled samples was excited at $339 \mathrm{~nm}$ and the emission was recorded in the range of 350-550 nm (2.5$\mathrm{nm}$ slit). Pyrene mobility was reflected as the yield of the excimer formation (excimer fluorescence-to-monomer fluorescence ratio monitored at $395 \mathrm{~nm}$ and $470 \mathrm{~nm}$, respectively), which directly depends on rate of the collision and on mutual distances of probe molecules in the lipid bilayer.

\section{Methods used in investigation of endogenous protective mechanisms localized on subcellular membrane systems in the heart}

\section{Estimation of sarcolemmal Na,K-ATPase activity}

Isolation of sarcolemmal membranes involved the treatments by hypotonic shock and with 0.6 mol..$^{-1}$ sodium iodide. The membrane fraction obtained in this manner contained less than $3 \%$ of sarcoplasmic reticulum and mitochondrial membranes. Na,K-ATPase activity is estimated on the base of inorganic phosphorus liberated by ATP splitting. For more details see Breier $e t$ al. (1995), Ziegelhöffer-Mihalovičová et al. (2003).

\section{Perfusion of the isolated rat heart and induction of calcium paradox:}

Rat hearts are quickly excised, cooled down, washed free of blood, placed in the perfusion device and "Langendorff"-perfused with Krebs-Henseleit (K-H) solution. After $15 \mathrm{~min}$ of stabilized perfusion at $37^{\circ} \mathrm{C}$ the following variations in perfusion conditions are applied: i) Control hearts perfused for further $15 \mathrm{~min}$ with the basic K-H solution; ii) Hearts with calcium paradox perfused for $3 \mathrm{~min}$ with calcium free K-H solution (calcium depletion) and subsequently for $10 \mathrm{~min}$ with $\mathrm{K}$ $\mathrm{H}$ solution containing $2.5 \mathrm{mmol}^{-\mathrm{l}^{-1}} \mathrm{Ca}^{2+}$ (calcium repletion). The function of perfused hearts is evaluated by monitoring $\mathrm{dp} / \mathrm{dt}_{\max }, \mathrm{dp} / \mathrm{dt}_{\min }$. For more details see Ravingerová et al. (1997), Ziegelhöffer-Mihalovičová et al. (2003).

Estimation of mitochondrial $\mathrm{Mg}^{2+}$-dependent 2,4-dinitrophenol stimulated ATPase activity

$\mathrm{Mg}^{2+}$-dependent 2,4-dinitrophenol stimulated ATPase, also termed as the total ATPase was assessed in isolated mitochondria by estimation of inorganic phosphorus liberated from ATP splitting. Contamination 
of the isolated mitochondrial fraction by other subcellular membranes was tested by estimation of marker ATPase activities of the sarcoplasmic reticulum and sarcolemma (Máleková et al. 2007) and it did not exceeded 2.2\%. For more details see Ferko et al. (2006), Mujkošová et al. (2008).

Estimation of conjugated dienes in cardiac mitochondrial membranes

Content of conjugated dienes in lipids of mitochondrial membranes was assessed by the method of Kogure et al. (1982) adapted to estimation of conjugated dienes in the membranes of heart mitochondria. Adaptation concerned the adjustment of optimal conditions for extraction of membrane lipids. For more details see Ziegelhöffer et al. (2009).

Cytochemical detection and quantitative determination of energy transition pores (contact sites) in heart mitochondria

The method for cytochemical detection of energy transition pores (ETP) is based on determination of the octameric mitochondrial isoform of the creatine kinase. The reaction of this enzyme is coupled to a series of subsequent reactions, the last being the reduction of thiocarbamyl nitroblue tetrazolium salt. After this step the sample becomes dehydrated, embedded in Epon 12 and further investigated in electron microscope. Detected contact sites are quantified by means of a stereological method and expressed in units of surface density. For more details see Ziegelhöffer-Mihalovičová et al. (1997).

\section{Experimental data and discussion}

In last 15-20 years the role of MF became investigated more intensively also in the membrane systems of the myocardium. A fast accumulating number of studies confirmed the regulatory role of MF for function of cardiac subcellular membrane systems in physiological and also in pathological conditions. Nevertheless, these studies also revealed that the simplified standard conception: "increased MF leads to augmented function of the membrane-bound systems", does not provide all information which may be obtained from MF investigation.

It was demonstrated that in streptozotocininduced experimental diabetes the calcium uptake of the heart exhibits a dramatical decrease as soon as $96 \mathrm{~h}$ after the injection of streptozotocin (Fig. 2; Gøtzsche 1991).
Time course after STZ for the induction of abnormal myocardial $\mathrm{Ca}$ uptake

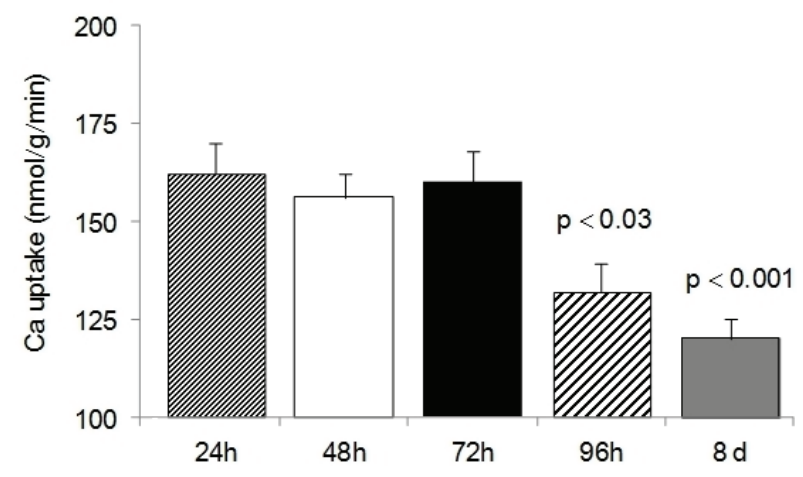

Fig. 2. Time course of myocardial calcium uptake after induction of experimental diabetes by application of streptozotocin. Data adapted, from the nomogram published by Gøtzsche (1991).

To explain the background of this phenomenon we investigated the fluidity of cardiac sarcolemma in similar conditions and revealed a marked $18.2 \%$ $(\mathrm{p}<0.05)$ increase in DPH anisotropy (Fig. 3) representing decreased MF that was also accompanied by a significant $33.7 \% \quad(\mathrm{p}<0.05)$ decrease in Na,K-ATPase activity (Ziegelhöffer et al.1997, Ziegelhöffer-Mihalovičová et al. 2003). The last two findings were in accordance with the expectations. Nevertheless a parallel $25.2 \%(p<0.05)$ increase in sarcolemmal $\mathrm{Mg} / \mathrm{Ca}-\mathrm{ATPase}$ activity was also registered (Ziegelhöffer et al. 1996). The latter discordance might result from the fact that although MF is regulatory to function of sarcolemmal components it may be itself regulated by several other factors and the diverse influences may interfere.

Fluorescence anisotropy

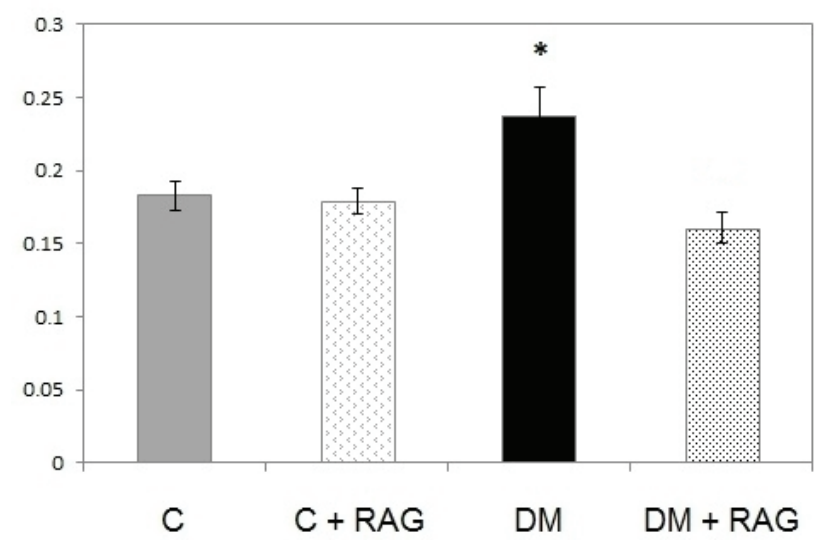

Fig. 3. Streptozotocin-diabetes and resorcylidene aminoguanidine (RAG)-induced changes in DPH anisotropy of the rat heart sarcolemma. Groups: DM - diabetes; DM+RAG - diabetes + treatment with RAG; C - healthy controls. Groups consisted of 12-15 hearts. 
It was hypothesised, that the decreased permeability of sarcolemma to calcium ions observed in diabetes (Fig. 2) may be caused, at least in part, by nonenzymatic glycation of proteins (NEGP) and the related free radical production in the sarcolemma. It was assumed that prevention of NEGP would also prevent the decrease in MF and via it normalize the activities of sarcolemmal enzymes. Application of resorcylidene aminoguanidine (RAG), a non-toxic compound with antiglycation and antioxidant effects (Čársky et al. 1978, Šikurová et al. 2000) indeed prevented completely the diabetes-induced decrease in MF and the sarcolemmal enzyme activities (Fig. 3; Ziegelhöffer-Mihalovičová et al. 2003). This testifies for modulation of MF by the processes of NEGP.

Preventing by RAG the diabetes-induced decrease in MF of the sarcolemma alleviated, to certain degree, the disturbances in cardiac function. But, on the other hand, it also weakened the capability of the heart to maintain adequate calcium handling.

\section{Survival of CaP in \%}

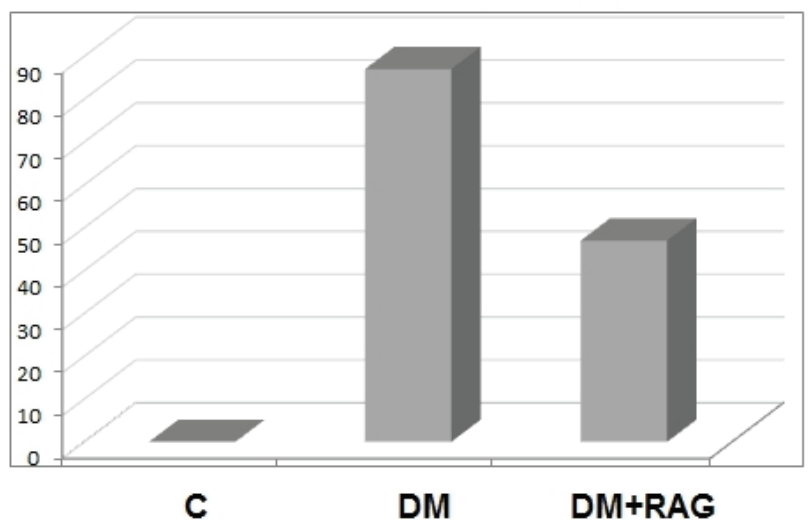

Fig. 4. Effect of calcium paradox and resorcylidene aminoguanidine (RAG) treatment on survival rate of isolated perfused diabetic hearts. Groups: D - diabetes; D+RAG diabetes + treatment with RAG; C - healthy controls. Groups consisted of $12-15$ hearts.

Isolated perfused hearts of rats with streptozotocin-diabetes showed massively depressed sensitivity to external calcium (Gøtzsche 1991). The latter feature was manifested in $83 \%$ survival of an extremely severe form o calcium overload, the calcium paradox. On the other hand, the survival rate in the group of RAG-treated diabetic hearts, which exhibited better preserved MF and sarcolemmal enzyme activities, was diminished to $47 \%$ only. None of the healthy control hearts survived the calcium paradox (Fig. 4). These findings indicated that low MF of cardiac sarcolemma is favourable for survival of the diabetic heart. It proved to be a powerful means of endogenous protection of the myocardium against overload with external calcium (Ravingerová et al. 1996, Ziegelhöffer et al. 1996).

In contrast to sarcolemma with decreased MF, the mitochondria from streptozotocin-diabetic rat hearts exhibited a significant $(\mathrm{p}<0.05), 83.3 \%$ increase in fluidity of the bulk of their membrane lipids (Ferko et al. 2006). This state may result from different parallel running processes: i) remodeling of composition of membrane lipids (Wojtzak et al. 1969) that may be induced either by diabetes itself or by pseudo-hypoxia. The latter novel term characterizes a state when hypoxia is not caused by lack of oxygen but by insufficiency of the respiratory chain to utilize $\mathrm{O}_{2}$ properly; ii) another process may be that the radicals produced in diabetic heart mitochondria are preferably extruded from mitochondria via the chloride channel (Máleková et al. 2007) instead to react with lipids inside the mitochondrial membrane; iii) third possible mechanism for keeping the MF of diabetic heart mitochondria elevated is associated with enhanced formation of energy transition pores (ETP) in mitochondrial membranes (Ziegelhöffer-Mihalovičová et al. 1997). These ephemeric structures, serving to high capacity energy transfer from the mitochondria to the cytoplasm, are bridging both mitochondrial membranes (Ziegelhöffer-Mihalovičová et al. 2002, Ziegelhöffer 2005, Ziegelhöffer et al. 2002, 2009). Their enhanced formation represents a compensatory response to increased energy demands of myocardial cells. This also indicates that ETP formation coupled with fluidization of the mitochondrial membrane belongs to mechanisms of endogenous protection of the myocardium. The process of MF elevation is initiated with the signal carried by increased calcium transients that leads to ETP formation in the mitochondrial membranes (Ziegelhöffer et al. 2002). ETPs are pulling both mitochondrial membranes close together and pushing aside the intramembrane fluid. The latter is than crowding in places between the ETPs and exerts elevated pressure on the lipid layers. Distances between the acyl chains of the membrane phospholipids increase and consequently the MF also increases (Ziegelhöffer 2005, Ziegelhöffer et al. 2009). This process can be demonstrated using the model of isolated perfused heart. Perfusion with elevated concentrations of calcium in perfusate increases considerably the number of mitochondrial ETP (Fig. 5) and subsequently also the MF (Fig. 6). 


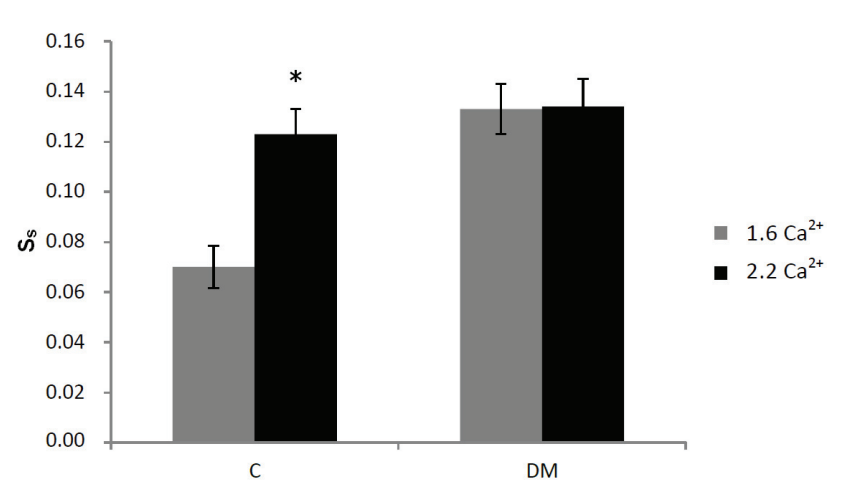

Fig. 5. Effect of calcium signaling on formation of energy transition pores in membranes of heart mitochondria. Groups: DM - diabetes; DM+RAG - diabetes + treatment with RAG; C healthy controls. Results are mean \pm S.E.M. from 10 experiments. $*$ significant at $\mathrm{p}<0.05$.

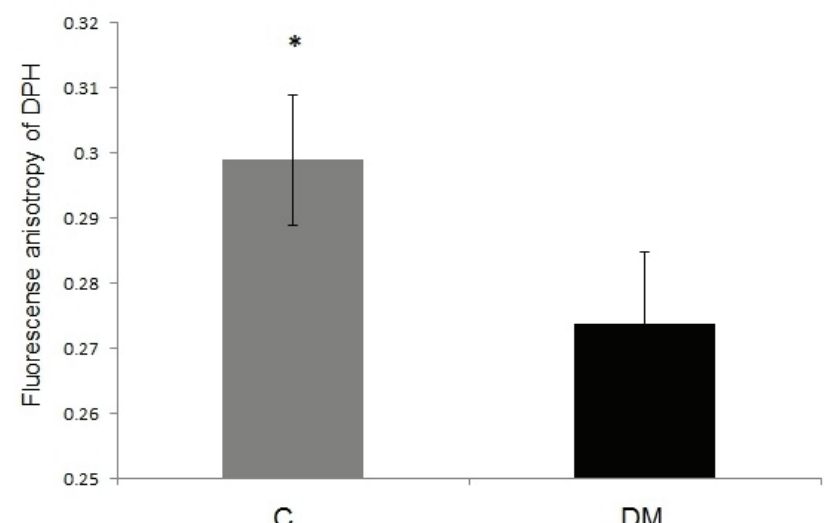

C

DM

Fig. 6. Effect of calcium signaling on membrane fluidity of heart mitochondria. Groups: DM - diabetes; C - healthy controls. Groups consisted of 12-15 hearts. Results are means \pm S.E.M. from 10 experiments. * significant at $\mathrm{p}<0.05$.
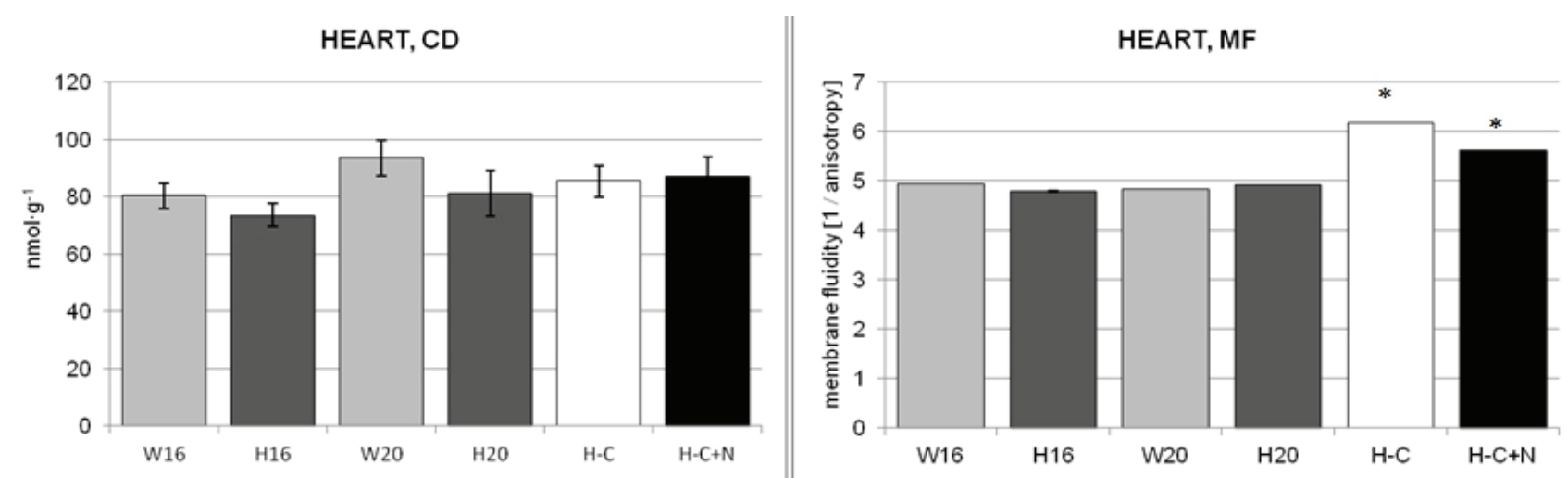

Fig. 7. Content of conjugated dienes (left hand pannel) and membrane fluidity (right hand panel) in heart mitochondria of spontaneosly hypertensive rats. CD - Conjugated dienes; MF - Membrane fluidity; W16 - 16 weeks old normotensive wistar contols; H16 - 16 weeks old hypertensive rats. Groups: W20 - 20 weeks old normotensive wistar controls; $\mathrm{H} 20$ - 20 weeks old hypertensive rats; $\mathrm{H}-\mathrm{C}-$ 20 weeks old hypertensive rats treated with captopril for 4 weeks; $\mathrm{H}-\mathrm{C}+\mathrm{N}-20$ weeks old hypertensive rats treated with captopril + nifedipine for 4 weeks; * significant at $\mathrm{p}<0.05$ against $\mathrm{H} 20$.

Surprisingly little information was available about function of heart mitochondria in spontaneous hypertension. It could be assumed that mitochondria of hypertensive hearts are not limited in access to oxygen but they experience increased energy demands originating from elevated work-load of the heart. This might induce a compensatory elevation of mitochondrial functions. Our results confirmed this assumption. Hypertensive heart mitochondria exhibited significantly $\left(\mathrm{p}<0.05\right.$ or more) increased $\mathrm{Mg}^{2+}$-ATPase activity and elevated parameters of ATP production in oxidative phosphorylation (Mujkošová et al. 2010) but, unchanged membrane fluidity (Fig. 7, right hand panel). For the latter finding we have no special explanation at present. Nevertheless, a lack of increase in concentration of the conjugated dienes (Fig. 7, left hand panel) excludes any participation of free radicals-induced lipid oxidation in this process.

On the other hand, treatment of hypertension with captopril or with captopril and nifedipine, both removed the hypertension efficiently and increased the MF of hypertensive heart mitochondria significantly (Fig. 7 right hand panel, $p<0.05$ or more). Mechanism of this effect is still investigated.

\section{Concluding remarks}

In our research, we have been oriented to extension of knowledge about the regulatory role of subcellular membranes for function of the heart in health and disease. We paid particular attention to elucidation of mutual interplay between biophysical, biochemical and physiological processes securing the function of subcellular membranes in diverse physiological situations 
and pathologies, particularly in diabetes.

In studies of abnormalities in calcium handling in the diabetic heart we have shown for the first time that decrease in fluidity of cardiac sarcolemma participates in protecting the diabetic heart against an overload with external calcium. This role makes modulation of MF to a means which may be utilized in endogenous protection of the myocardium.

We have reported for the first time the simultaneous measurements of membrane potential and dynamics as well as respiratory chain activities in the cardiac mitochondria under diabetic conditions. We have also shown that some of the processes regulating ATP production in the diabetic heart occur at the membrane level. Our results have pointed to the fact that not all changes triggered by some pathological impulse seem to be pathognomonic, but may represent compensatory and adaptive responses to the disease. It is necessary to emphasize that the latter assumption bears several important consequences: 1) the preconditioning-like protective and adaptive responses, discussed in detail by Ferdinandy et al. (1998), may be adequate to maintain the overall contractile performance of the diabetic heart at relatively normal levels, at least for a certain time; 2) the adaptive mechanisms start to develop in the cardiac myocytes; 3) it is highly probable that the observed fluidization of mitochondrial membranes with concomitant increase in mitochondrial ATPase activity and changes in membrane potential serve adaptive functions in the mitochondria of diabetic heart. Nevertheless, the mechanism of partnership of these 3 factors in processes of endogenous protection still requires some more elucidation.

It may be concluded that focused coordination of biophysical, biochemical and physiological approaches may also in future open new insights in the regulatory role of subcellular membranes in heart function.

\section{Conflict of Interest}

There is no conflict of interest.

\section{Acknowledgements}

We would like to thank all the people who have been involved in the experiments or provided assistance, advice and support essential to the research projects, particularly to Jozef Č́rsky, Barbara Ziegelhöffer, František Kolár̆, Tibor Ziegelhöffer, Ol'ga Uličná, Jan Neckár̆, Norbert Vrbjar and many others. We also thank to Zlatica Hradecká, Erika Havránková, Mária Kollárová and Miroslava Zádorová for the excellent technical assistance. This study was supported by the grants VEGA: 2/0101/12, 2/0054/11, 1/0638/12, 1/0668/11, KEGA 003UK-4/2012 and APVV-LPP-0393-09.

\section{References}

BAKKER A, BERNAERT I, DE BIE M, RAVINGEROVA T, ZIEGELHÖFFER A, VAN BELLE H, JACOB W: The effect of calcium on mitochondrial contact sites: a study on isolated rat hearts. Biochim Biophys Acta 1224: 583-588, 1994.

BARENHOLZ Y, COHEN T, HAAS E, OTTOLENGHI M: Lateral organization of pyrene-labeled lipids in bilayers as determined from the deviation from equilibrium between pyrene monomers and excimers. J Biol Chem 271: 3085-3090, 1996.

BREIER A, ZIEGELHÖFFER A, STANKOVIČOVÁ T, DOČOLOMANSKÝ P, GEMEINER P, VRBANOVÁ A: Inhibition of $(\mathrm{Na}, \mathrm{K})-\mathrm{ATPase}$ by electrophilic substances: functional implications. Mol Cell Biochem 147: 193$196,1995$.

CAGALINEC M, KYSELOVIC J, BLASKOVA E, BACHAROVA L, CHORVAT D Jr, CHORVATOVA A: Comparative study of the effects of lacidipine and enalapril on the left ventricular cardiomyocyte remodeling in spontaneously hypertensive rats. J Cardiovasc Pharmacol 47: 561-570, 2006.

ČÁRSKY J, LAZAROVÁ M, BEŇO A: Study of resorcylidene aminoguanidine. I. Spectral and acid-basic properties of the onium compounds. Acta Fac Rerum Nat Univ Comen Chimia 26: 89-102, 1978.

DHALLA NS, ZIEGELHÖFFER A, HARROW JAC: Regulatory role of membrane systems in heart function. Can $J$ Physiol Pharmacol 55: 1211-1234, 1977.

DOBACZEWSKI M, KAZMIERCZAK P, RAVINGEROVÁ T, ULIČNÁ O, NOCUN M, WACZULÍKOVÁ I, MARKUSZEWSKI L, WATALA C: Ex vivo detection of rat coronary endothelial dysfunction in diabetes mellitus: methodological considerations. Methods Find Exp Clin Pharmacol 28: 507-513, 2006. 
FERDINANDY P, SZILVASSY Z, BAXTER GF: Adaptation to myocardial stress in disease states: is preconditioning a healthy heart phenomenon? Trends Pharmacol Sci 19: 223-229, 1998.

FERKO M, GVOZDJAKOVÁ A, KUCHARSKÁ J, MUJKOŠOVÁ J, WACZULÍKOVÁ I, STYK J, RAVINGEROVÁ T, ZIEGELHÖFFER-MIHALOVIČOVÁ B, ZIEGELHÖFFER A: Functional remodeling of heart mitochondria in acute diabetes: interrelationships between damage, endogenous protection and adaptation. Gen Physiol Biophys 25: 397-413, 2006.

FERKO M, HABODÁSZOVÁ D, WACZULÍKOVÁ I, MUJKOŠOVÁ J, KUCHARSKÁ J, ŠIKUROVÁ L, ZIEGELHÖFFER B, STYK J, ZIEGELHÖFFER A: Endogenous protective mechanisms in remodeling of rat heart mitochondrial membranes in the acute phase of streptozotocin-induced diabetes. Physiol Res $\mathbf{5 7}$ (Suppl 2): S67-S73, 2008.

GENNIS RB: Biomembranes. Molecular Structure and Function. CR CANTOR (ed), Springer-Verlag, New York, 1989, p. 533.

GØTZSCHE O: Myocardial calcium uptake and catecholamine sensitivity in experimental diabetes. In: The Diabetic Heart. M NAGANO, NS DHALLA (eds), Raven Press, New York, 1991, pp 229-236.

KASS M, WITKIN A, TERZOPOULOS D: Snakes: active contour models. Int J Comput Vis 1: 321-331, 1988.

KNOLL G, BRDICZKA D: Changes in freeze fractured mitochondrial membranes correlated to their energy state: dynamic interactions of the boundary membranes. Biochim Biophys Acta 733: 102-110, 1983.

KOGURE K, WATSON BD, BUSTO R, ABE K: Potentiation of lipid peroxides by ischemia in rat brain. Neurochem Res 7: 437-454, 1982.

MÁLEKOVÁ L, KOMÍNKOVÁ V, FERKO M, ŠTEFÁNIK P, KRIŽANOVÁ O, ZIEGELHÖFFER A, SZEWCZYK A, ONDRIÁŠ K: Bongkrekic acid and atractyloside inhibits chloride channels from mitochondrial membranes of rat heart. Biochem Biophys Acta 1767: 31-44, 2007.

MUJKOŠOVÁ J, FERKO M, HUMENÍK P, WACZULÍKOVÁ I, ZIEGELHÖFFER A: Seasonal variations in properties of healthy and diabetic heart mitochondria: $\mathrm{Mg}^{2+}$-ATPase activity, content of conjugated dienes and membrane fluidity. Physiol Res 57 (Suppl 2): S75-S82, 2008.

MUJKOŠOVÁ J, ULIČNÁ O, WACZULÍKOVÁ I, VLKOVIČOVÁ J, VANČOVSKÁ O, ZIEGELHÖFFER A: Mitochondrial function in heart and kidney of spontaneously hypertensive rats: influence of captopril treatment. Gen Physiol Biophys 29: 203-207, 2010.

PIERCE GN, DHALLA NS: Heart mitochondrial function in chronic experimental diabetes in rats. Can J Cardiol 1: 48-54, 1985.

PIERCE GN, NAGANO M, ZAHRADKA P, DHALLA NS (eds): Atherosclerosis, Hypertension and Diabetes. Kluwer Academic Publishers, Norwell, 2003.

RAVINGEROVÁ T, STYK J, PANCZA D, TRIBULOVÁ N, ŠEBOKOVÁ J, VOLKOVOVÁ K, ZIEGELHÖFFER A, SLEZÁK J: Diabetic cardiomyopathy in rats: alleviation of myocardial dysfunction caused by $\mathrm{Ca}^{2+}$-overload. Diabetes Res Clin Pract 31 (Suppl): S105-S112, 1996.

RAVINGEROVA T, WU S, PANCZA D, DŽURBA A, ZIEGELHÖFFER A, PARRATT J: Pretreatment with catecholamines can suppress severe ventricular arrhythmias in rats: relevance to ischemic preconditioning. Exp Clin Cardiol 2: 19-25, 1997.

RAVINGEROVA T, PANCZA D, VOLKOVOVA K, DZURBA A, STETKA R, ZIEGELHÖFFER A, STYK J: Response to myocardial ischemia is modulated in diabetic rat heart: adaptation to disease? Exp Clin Cardiol 3: 122-128, 2000.

SCHWARTZ A: Electron transport and mitochondria. Cardiology 56: 35-42, 1971/1972.

SHINITZKY M: Membrane fluidity and cellular functions. In: Physiology of Membrane Fluidity. M. SHINITZKY (ed), CRC Press, Boca Raton, 1984, pp 1-51.

ŠIKUROVÁ L, NEMCOVÁ P, KVASNIČKA P, HIANIK T: Fluorescence anisotropy studies of ACTH interaction with lecitin bilayers. J Fluoresc 7 (Suppl): 151S-154S, 1997.

ŠIKUROVÁ L, DÉREROVÁ J, KVASNIČKA P, WACZULÍKOVÁ I, ČÁRSKY J, ULIČNÁ O: Resorcylidene aminoguanidine improves the pathologically reduced fluidity of erythrocyte membranes in diabetes mellitus. Pharmazie 55: 700-701, 2000. 
SLEZÁK P, ŠIKUROVÁ L: Influence of storage of insulated erythrocytes membranes on membrane. In: Proceedings of the III. Slovak Biophysical Symposium, Bratislava, 18.-20.4.2008, FMFI UK, Bratislava, 2008, pp 65-66.

SORDAHL LA, SCHWARTZ A: Effects of dipyridamole on heart muscle mitochondria. Mol Pharmacol 3: 509-516, 1967.

TAAM GML, TAKEO S, PANAGIA V, ZIEGELHÖFFER A, DHALLA NS: Changes in subcellular membranes in rat heart perfused with diethyl ether. Can J Physiol Pharmacol 57: 1412-1420, 1979.

ULIČNÁ O, VANČOVÁ O, WACZULÍKOVÁ I, BOŽEK P, JANEGA P, BABÁL P, LÍŠKOVÁ S: Does rooibos tea (Aspalathus linearis) support regeneration of rat liver after intoxication by carbon tetrachloride? Gen Physiol Biophys 27: 179-186, 2008.

WACZULÍKOVÁ I, ŠIKUROVÁ L, BRYSZEWSKA M, REKAWIECKA K, ČÁRSKY J, ULIČNÁ O: Impaired erythrocyte transmembrane potential in diabetes mellitus and its possible improvement by resorcylidene aminoguanidine. Bioelectrochemistry 52: 251-256, 2000.

WACZULÍKOVÁ I, ZIEGELHÖFFER A, ORSZÁGHOVÁ Z, ČÁRSKY J: Fluidising effect of resorcylidene aminoguanidine on sarcolemmal membranes in streptozotocin-diabetic rats: blunted adaptation of diabetic myocardium to $\mathrm{Ca}^{2+}$ overload. J Physiol Pharmacol 53: 727-739, 2002.

WACZULÍKOVÁ I, HABODASZOVÁ D, CAGALINEC M, FERKO M, ULIČNÁ O, MATEAŠIK A, ŠIKUROVÁ L, ZIEGELHÖFFER A: Mitochondrial membrane fluidity, potential, and calcium transients in the myocardium from acute diabetic rats. Can J Physiol Pharmacol 85: 372-381, 2007.

WACZULÍKOVÁ I, KINCELOVÁ D, CAGALINEC M, ULIČNÁ O, FERKO M, MUJKOŠOVÁ J, RAVINGEROVÁ T, ZIEGELHÖFFER A, ŠIKUROVÁ L: Biophysical methodology helps to provide insight into the changes in heart caused by streptozotocin-induced diabetes and hypertension. In: Experimental Approaches in Basic Research and Diagnostic of Diseases: Tailoring the Treatment. N TRIBULOVÁ, L' OKRUHLICOVÁ, J SLEZÁK (eds), VEDA, Bratislava, 2008, pp 91-103.

WACZULÍKOVÁ I, SLEZÁK P: Statistics in Medical Research. Radiology IV: Uroradiology. VEDA, Bratislava, 2009.

WACZULÍKOVÁ I, CAGALINEC M, ULIČNÁ O, SLEZÁK P, ZIEGELHÖFFER A: Biophysical investigation of left ventricular myocytes in rats with experimentally induced diabetes. Physiol Res 59 (Suppl 1): S9-S17, 2010.

WATALA C: Altered structural and dynamic properties of blood cell membranes in diabetes mellitus. Diabetic Med 10: 13-20, 1993.

WATALA C, WACZULÍKOVÁ I, WIECLAWSKA B, ROZALSKI M, GREŠNER P, GWOŹDZIŃSKI K, MATEAŠIK A, ŠIKUROVÁ L: Merocyanine 540 as a fluorescent probe of altered membrane phospholipid asymmetry in activated whole blood platelets. Cytometry 49: 119-123, 2002.

WOJTZAK L, BOGUCKA K, SARZALA MG, ZALUSKA H: Effect of fatty acids on energy metabolism and the transport of adenine nucleotides in mitochondria and other cellular structures. In: FEBS Symposium. Mitochondria, Structure and Function. Vol. 17. L ERNSTER, Z DRAHOTA (eds), Academic Press, London, 1969, pp 79-92.

ZIEGELHÖFFER A, RAVINGEROVÁ T, STYK J, TRIBULOVÁ N, VOLKOVOVÁ K, ŠEBOKOVÁ J, BREIER A: Diabetic cardiomyopathy in rats: biochemical mechanisms of increased tolerancee to calcium overload. Diabetes Res Clin Pract 31 (Suppl): S93-S103, 1996.

ZIEGELHÖFFER A, RAVINGEROVÁ T, STYK J, ŠEBOKOVÁ J, WACZULÍKOVÁ I, BREIER A, DŽURBA A, VOLKOVOVÁ K, ČÁRSKY J, TURECKÝ L: Mechanisms that may be involved in calcium tolerance of the diabetic heart. Mol Cell Biochem 176: 191-198, 1997.

ZIEGELHÖFFER A, KJELDSEN K: BUNDGAARD H, BREIER A, VRBJAR N, DŽURBA A: Na,K-ATPase in the myocardium. Molecular principles, functional and clinical aspects. Gen Physiol Biophys 19: 9-47, 2000.

ZIEGELHÖFFER A, RAVINGEROVÁ T, WACZULÍKOVÁ I, ČÁRSKY J, NECKÁŘ J, ZIEGELHÖFFERMIHALOVIČOVÁ B, STYK J: Energy transfer in acute diabetic rat hearts. Adaptation to increased energy demands due to augmented calcium transients. Ann N Y Acad Sci 967: 463-468, 2002.

ZIEGELHÖFFER A, BUNDGAARD H, RAVINGEROVÁ T, TRIBULOVÁ N, ENEVOLDSEN MT, KJELDSEN K: Diabetes and semi-starvation-induced changes in metabolism and regulation of Na,K-ATPase in rat heart. Diab Nutr Met 16: 222-231, 2003a. 
ZIEGELHÖFFER A, WACZULÍKOVÁ I, RAVINGEROVÁ T, ZIEGELHÖFFER-MIHALOVIČOVÁ B, NECKÁŘ J, STYK J: Augmented energy transfer in rat heart mitochondria: compensatory response to abnormal household of energy in acute diabetes. In: Atherosclerosis, Hypertension and Diabetes. GN PIERCE, M NAGANO, P ZAHRADKA, NS DHALLA (eds), KLUWER Academic Publishers, Boston, 2003b, pp 439-453.

ZIEGELHÖFFER A: Endogenous protective mechanisms in the heart triggered by acute streptozotocin-diabetes. In: Experimental Hypertension and Ischemic Heart Disease. L BACHÁROVÁ, J KYSELOVIČ, J SLEZÁK (eds), VEDA, Publishing House of the Slovak Academy of Sciences, Bratislava, 2005, pp 193-208.

ZIEGELHÖFFER A, WACZULÍKOVÁ I, FERKO M, KINCELOVÁ D, ZIEGELHÖFFER B, RAVINGEROVÁ T, CAGALINEC M, SCHÖNBURG M, ZIEGELHÖFFER T, ŠIKUROVÁ L, ULIČNÁ O, MUJKOŠOVÁ J: Calcium singaling-mediated endogenous protection of cell energetics in the acutely diabetic myocardium. Can J Physiol Pharmacol 87: 1083-1094, 2009.

ZIEGELHÖFFER-MIHALOVIČOVÁ B, OKRUHLICOVÁ L', TRIBULOVÁ N, RAVINGEROVÁ T, VOLKOVOVÁ K, ŠEBOKOVÁ J, ZIEGELHÖFFER A: Mitochondrial contact sites detected by creatine phosphokinase activity in the hearts of normal and diabetic rats: Is the contact sites formation a calcium-dependent process? Gen Physiol Biophys 16: 329-338, 1997.

ZIEGELHÖFFER-MIHALOVIČOVÁ B, ZIEGELHÖFFER A, RAVINGEROVÁ T, KOLÁŘ F, JACOB W, TRIBULOVÁ N: Regulation of myocardial contact sites in neonatal, juvenile and diabetic hearts. Mol Cell Biochem 236: 37-44, 2002.

ZIEGELHÖFFER-MIHALOVIČOVÁ B, WACZULÍKOVÁ I, ŠIKUROVÁ L, STYK J, ČÁRSKY J, ZIEGELHÖFFER A: Remodelling of the sarcolemma in diabetic rat hearts: the role of membrane fluidity. Mol Cell Biochem 249: 175-182, 2003.

ZVARÍK M, ŠIKUROVÁ L: Monitoring possibilities of the mitochondrial membrane potential by a thiadicarbocyanine tribromide fluroscent probe. In: Proceedings of the III. Slovak Biophysical Symposium. FMFI UK, Bratislava, 2008, pp 51-52. 